\title{
Biofertilizers in horticultural crops
}

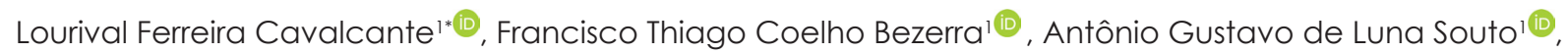

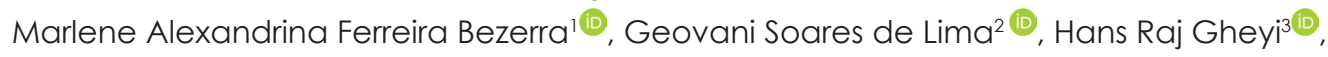

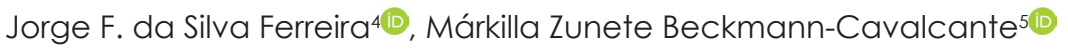

\author{
'Federal University of Paraíba, Areia, Brazil \\ ${ }^{2}$ Federal University of Campina Grade, Pombal, Brazil \\ ${ }^{3}$ Federal University of Recôncavo Da Bahia, Cruz das Almas, Brazil \\ ${ }^{4}$ United States Department of Agriculture/Salinity Laboratory, Riverside, USA \\ ${ }^{5}$ Federal University of São Francisco Valley, Petrolina, Brazil \\ *Corresponding author, e-mail: lofeca@cca.ufpb.br
}

\begin{abstract}
Bovine manure biofertilizers can exert physical, chemical, and biological effects on the soil and the phytoprotective, physiological, and productive actions in horticultural crops. The literature review was performed to compile information on the production, uses, and effects of bovine manure biofertilizers on soil properties and plants. Biofertilizers are produced by organic components, minerals, and inoculants. Among the organic sources, the bovine manure is the most used. The fermentation of the bovine manure in water constitutes the Vairo biofertilizer, the most employed in Brazilian horticulture. With the chemical enrichment of this preparation came the Supermagro, Agrobio, and Agrobom biofertilizers. In the soil, it can act in the improvement of soil fertility, physical properties, and in the diversity and abundance of the biota. Also, it can act in control of pests and diseases, leaf composition concerning macro and micronutrients, and in the production and postharvest quality of horticultural crops. Therefore, this review describes the preparation, chemical composition, and utilization of bovine manure biofertilizers in both soil and plants, offering perspectives of research on the formulations, application, and effects of these inputs on horticultural species.
\end{abstract}

Keywords: fruit crops, organic input, vegetable crops

\section{Introduction}

The continuous and excessive use of agrochemicals and synthetic mineral fertilizers has sometimes led to the physical, chemical, and biological degradation of soils and pollution of water sources and atmosphere, both in agricultural and natural environments, besides promoting physiological disorders in the plants. According to Araújo (2010), nothing can be more emblematic than these types of problems caused by the conventional way of agricultural production, generating a considerable number of negative externalities. In this perspective, the world has sought strategies related to the development and diffusion of environmentally adequate technologies (Chaboussou, 2012; Sambuichi et al., 2012), not only in conflict with the conventional production model but also as an alternative and complement to the traditional inputs and productive systems.

Accordingly, a low-impact and highly productive agriculture must be prioritized as a strategy for feeding future generations (Tal, 2018), highlighting the use of liquid biofertilizers as an efficient alternative to reduce costs and improve the environmental quality (Santos \& Akiba,
1996; Fernandes et al., 2000; Cavalcante et al., 201 la; Wang et al., 2019). In Brazil, these inputs are produced via fermentation of an organic component (Santos, 1992; Fernandes et al., 2000; Silva et al., 2007a; Gonçalves et al., 2009). However, in other countries, formulations based on strains of Azotobacter, Rhizobium, Azospirillum, mycorrhizas, and a mix of microorganisms are also called biofertilizers (Araújo, 2010; Mangalassery et al., 2019).

According to the Brazilian legislation, Federal Decree $n^{\circ} 4.954 / 2004$, the biofertilizer is "a product that contains an active principle or organic agent, free of agrotoxins able to act, either directly or indirectly, on the totality or on part of the cultivated plants, raising the productivity while not considering their hormonal or stimulating value" (Brasil, 2004). The biofertilizer, according to Santos (1992), is a pasty effluent that results from the fermentation of the organic matter under the total absence of atmospheric oxygen. Alves et al. (2001) define the biofertilizer as a bioactive compound, the final residue of the fermentation of the organic matter, which contains live or latent microorganism cells, and its metabolites and agromineral chelates. 
The preparation of biofertilizers employ, as sources of organic matter, leftover fruits in the property, vermicompounds, plants and/or fresh manures (Gonçalves et al., 2009). Goat manure (Leonel et al., 2015), swine manure (Veroneze et al., 2019), crab remains (Sousa et al., 2016), and bovine manure (Santos, 1992; Duenhas, 2004; Cavalcante et al., 2008; Alves et al., 2009; Mesquita et al., 2010; Dias et al., 2011; Cavalcante et al., 2012; Chiconato et al., 2013; Santos et al., 2014; Nascimento et al., 2015; Santana et al., 2016; Aguiar et al., 2017; Veras et al., 2018; Wang et al., 2019) are commonly employed, with the last one being the most used.

The use of bovine manure biofertilizer is based on its effects on the edaphic (Mellek et al., 2010; Cavalcante et al., 2011a; Oliveira et al., 2014; Wang et al., 2019), phytoprotective (Santos, 1992; Rampelotto et al., 2013; Shivlata \& Satyanarayana, 2015), nutritional (Mesquita et al., 2010; Cavalcante et al., 2012), physiological (Cavalcante et al., 201 1b; Viana et al., 2013; Lima Neto et al., 2018) and productive attributes in horticultural species (Mesquita et al., 2007; Silva et al., 2012; Chiconato et al., 2014; Aguiar et al., 2017; Nunes et al., 2018).

Therefore, this review aimed to compile information on the production, use, and effects of the bovine manure biofertilizer on the soil and plants.

\section{Production of bovine manure biofertilizers}

Considering a socio-environmental approach, the biofertilizer should be prepared based on inputs of the rural property itself. The production of this organic fertilizer through the anaerobic fermentation of the fresh bovine manure diluted in an equivalent volume of nonchlorinated water, called common biofertilizer, or Vairo (Santos, 1992; Santos \& Akiba, 1996), is one of the most used inputs in horticultural studies in Brazil. However, there are variations in the constituents and processes of production, being also obtained through aerobic fermentation (Medeiros et al., 2003; Araújo, 2010; Wang et al., 2019).

The bovine manure biofertilizer, according to Araújo (2010) can be obtained by processes of anaerobic fermentation (hermetically closed container, without contact with atmospheric oxygen), semi-aerobic fermentation (contact with atmospheric air), and aerobic (with forced aeration). In the anaerobic fermentation, the process is faster and with lower nutrient loss (Santos \& Akiba, 1996). The digestion period is related to the temperature, with the mesophilic digestion - optimal between 30 and $40{ }^{\circ} \mathrm{C}$ - needing less than 30 days to conclude the process, which can be anticipated under thermophilic digestion - optimal between 45 and $57^{\circ} \mathrm{C}$ (Santos \& Akiba, 1996). However, for these authors, the optimal temperature ranges between 30 and $35^{\circ} \mathrm{C}$.

The process of anaerobic fermentation can be divided into four sequenced stages: hydrolysis, acidogenesis, acetogenesis, and methanogenesis (Vavilin et al., 1996; Soares et al., 2017). In hydrolysis, the complex organic matter (carbohydrates, proteins, and lipids) is broken into simpler soluble materials (sugars, amino acids, and long-chain fatty acids). These materials, in acidogenesis, are absorbed and metabolized by fermentative bacteria, producing volatile fatty acids, alcohols, lactic acid, and mineral compounds $\left(\mathrm{CO}_{2}, \mathrm{H}_{2^{\prime}}\right.$ $\mathrm{NH}_{3}, \mathrm{H}_{2} \mathrm{~S}$ ). During acetogenesis, the Archaeas transform the products of the acidogenic stage into acetate, hydrogen, and carbon dioxide. In the final stage, methanogenesis, the production of methane and carbon dioxide occurs.

According to Gonçalves et al. (2009), biofertilizers must be prepared with organic compounds (fresh manures, fruits, vermicompounds, and/or plant parts), minerals (non-chlorinated water, rock powders, ashes, limestone, natural phosphate and/or soluble salts), and an inoculant (milk, salt-free whey, and/or an inoculant material), also allowing to add sugar or molasses to add energy and increase fermentation. The fermentation anaerobic of the bovine manure diluted in water gives origin to the Vairo or common biofertilizer (Santos, 1992), and the incorporation of other minerals and/or inoculants sets it apart from enriched biofertilizers, such as the Supermagro (Trés \& Resende, 1995), Agrobio (Fernandes, 2000) and the Agrobom (Silva et al., 2007a), under aerobic fermentation.

The Supermagro biofertilizer, a homage to its creator, Delvino Magro, employs 100 L of water, 20 $\mathrm{L}$ of fresh manure, and a protein mixture of $500 \mathrm{~g}$ of brown sugar, $200 \mathrm{~g}$ of calcific limestone, $200 \mathrm{~g}$ of araxá phosphate, $200 \mathrm{~g}$ of bone powder, $100 \mathrm{~g}$ of fresh bovine liver, $0.1 \mathrm{~L}$ of bovine blood and $1 \mathrm{~L}$ of cow milk or whey. Every three days, a salt mixture and a protein mixture are added. The first mixture is composed of $300 \mathrm{~g} \mathrm{of} \mathrm{CuSO}_{4^{\prime}}$ $300 \mathrm{~g}$ of $\mathrm{FeSO}_{4^{\prime}} 300 \mathrm{~g}$ of $\mathrm{MnSO}_{4^{\prime}}$ and $2.000 \mathrm{~g}$ of $\mathrm{ZnSO}_{4^{\prime}}$ incorporating $1.000 \mathrm{~g}$ on the fourth and seventh days and $900 \mathrm{~g}$ of the mixture on the tenth day. The second mixture employs $1.000 \mathrm{~g}$ of $\mathrm{H}_{3} \mathrm{BO}_{3}$ and $2.000 \mathrm{~g}$ of $\mathrm{CaCl}_{2}$, divided equally into three applications. The third mixture consists of $50 \mathrm{~g}$ of $\mathrm{CoSO}_{4}$ and $2.000 \mathrm{~g}$ of $\mathrm{MgSO}_{4}$, applied in two doses. On the twenty-fifth day, $100 \mathrm{~g}$ of $\mathrm{Na}_{2} \mathrm{MoO}_{4}$ was added, being considering ready for use five days after this last salt addition (Trés \& Resende, 1995). 
The Agrobio biofertilizer was derived from the Supermagro, being prepared with $200 \mathrm{~L}$ of water, $100 \mathrm{~L}$ of fresh manure, $20 \mathrm{~L}$ of cow milk or whey, and $3.000 \mathrm{~g}$ of molasses (Fernandes, 2000). In the fifty subsequent days of this mixture, $430 \mathrm{~g}$ of $\mathrm{H}_{3} \mathrm{BO}_{3}$ or $\mathrm{Na}_{2}\left[\mathrm{~B}_{4} \mathrm{O}_{5}(\mathrm{OH})_{4}\right], 570 \mathrm{~g}$ of wood ash, $850 \mathrm{~g}$ of $\mathrm{CaCl}_{2}, 43 \mathrm{~g}$ of $\mathrm{FeSO}_{4^{\prime}} 60 \mathrm{~g}$ of bone powder, $60 \mathrm{~g}$ of meat powder, $143 \mathrm{~g}$ of magnesian thermo phosphate, $1.500 \mathrm{~g}$ of molasses, $30 \mathrm{~g}$ of $\mathrm{Na}_{2} \mathrm{MoO}_{4^{\prime}} 30 \mathrm{~g}$ of $\mathrm{CoSO}_{4^{\prime}} 43 \mathrm{~g}$ of $\mathrm{CuSO}_{4^{\prime}} 86 \mathrm{~g}$ of $\mathrm{MnSO}_{4^{\prime}} 143 \mathrm{~g}$ of $\mathrm{MgSO}_{4^{\prime}}$ $57 \mathrm{~g}$ of $\mathrm{ZnSO}_{4}, 29 \mathrm{~g}$ of castor pie, and 30 drops of a $1 \%$ alcoholic iodine solution $1 \%$ were weekly incorporated. During the last four weeks, $0.5 \mathrm{~L}$ of cow urine was added, and after eight weeks the volume was completed with water until $500 \mathrm{~L}$, homogenizing it twice a day.

An inoculum is used in the Agrobom biofertilizer, adapted from the Agrobio and known as a spray of trace elements (Silva et al., 2007a). The inoculum consists of $1 \mathrm{~L}$ of water, $1 \mathrm{~L}$ of fresh manure, $0.5 \mathrm{~L}$ of milk, $0.25 \mathrm{~L}$ of fruit or vegetable juice, $700 \mathrm{~g}$ of chicken manure, 1 teaspoon of natural phosphate, 1 teaspoon of oven ashes, and 1 soup spoon of rock powder rich is silica, which must be exposed to the sun and covered with a black canvas for $72 \mathrm{~h}$. This preparation is followed by the mixing of $40,000 \mathrm{~g}$ of fresh manure, $5 \mathrm{~L}$ of molasses or 1,000 $\mathrm{g}$ of "rapadura" (hard sweet), 1,000 $\mathrm{g}$ of the inoculum and a salt mixture that is added for three more consecutive weeks. The added salts are 4 soup spoons of dolomitic limestone, 4 soup spoons of rock powder rich in silica, 1 teaspoon of natural phosphate, 1 of Borax, 1 of $\mathrm{FeCl}_{3}, 1$ of $\mathrm{MgSO}_{4}, 5$ of $\mathrm{Na}_{2} \mathrm{MoO}_{4^{\prime}} 1$ coffee spoon of $\mathrm{ZnSO}_{4}$ and $\mathrm{MnSO}_{4^{\prime}}$ and 10 drops of $10 \%$ iodine.

\section{Analyses and composition of the biofertilizers}

The determination of the chemical composition of the Vairo biofertilizer is performed as soluble ions
(Santos, 1992; Alves et al., 2009; Dias et al., 201 1; Marrocos et al., 2012; Chiconato et al., 2013; Oliveira et al., 2013; Alencar et al., 2015; Nascimento et al., 2015; Silva et al., 2016a; Souza et al., 2016; Santana et al., 2016; Aguiar et al., 2017) or dry matter components (Duenhas, 2004; Rodolfo Júnior et al., 2009; Mesquita et al., 2010; Dutra et al., 2016; Aguiar et al., 2017; Mesquita et al., 2017; Wang et al., 2019). However, the literature also allows observing similar analyses to those determined in soil fertility based on the dry matter of the biofertilizer (Araújo et al., 2013; Santos et al., 2014; Veras et al., 2018). Through the different evaluation methods, the need for the standardization of the sample and characterization as to ease the comparisons and inferences between results can be noted.

When considering that the fresh bovine manure might contain more than $80 \%$ of water (Santos \& Akiba, 1996; Matos et al., 2017), and in the Vairo biofertilizer the manure is diluted in an equal volume of water for the fermentation (Santos, 1992; Santos \& Akiba, 1996), it would be adequate that the chemical determinations were performed as soluble ions. The dry matter during the anaerobic fermentation of the manure is reduced (Marrocos et al., 2012), with the predominance of the soluble material in the biofertilizer (Matos et al., 2017). These authors produced a biofertilizer with $93.5 \%$ of water and also highlighted that the production management systems of dairy cows (organic and conventional) influence the chemical and physico-chemical characteristics of the animal wastes and, consequently, in the biofertilizers. The manure of dairy cows is the most recommended due to the balanced feeding with regard to the components of the diet (Santos, 1992). Therefore, expressive variations in the concentrations of the soluble ions of the biofertilizer were verified (Table 1).

Table 1. Soluble mineral components of the Vairo biofertilizer.

\begin{tabular}{|c|c|c|c|c|c|c|c|c|c|c|c|c|c|c|c|}
\hline Ref & $\mathrm{pH}$ & CE & $N$ & $P$ & K & $\mathrm{Ca}$ & $\mathrm{Mg}$ & $S$ & $\mathrm{Fe}$ & $M n$ & $\mathrm{Zn}$ & $\mathrm{Cu}$ & $B$ & $\mathrm{Cl}$ & $\mathrm{Na}$ \\
\hline & -- & $\mathrm{d} S \mathrm{~m}^{-1}$ & & & - & -1 ------ & & & & & --- mg L & & & & \\
\hline 1 & 7.80 & - & - & 0.55 & 0.97 & 1.30 & 0.32 & 0.18 & 44.7 & 16.60 & 6.70 & 1.1 & 1.1 & 1,160 & 166.0 \\
\hline 2 & - & - & 0.25 & 0.08 & 0.11 & 4.30 & 0.10 & 5.47 & 6.04 & 3.67 & 2.05 & 0.03 & 1.38 & - & 16.6 \\
\hline $3^{* *}$ & 6.55 & 2.76 & - & - & 0.31 & 0.08 & 0.09 & 0.08 & - & - & - & - & - & 773.2 & 184.6 \\
\hline $4^{*}$ & 7.88 & 4.69 & 0.09 & 0.03 & 0,68 & 0.03 & 0.01 & - & - & - & - & - & - & - & - \\
\hline 5 & - & - & 14.00 & 5.40 & 4.80 & 6.50 & 2.60 & 2.00 & 1.0 & 0.20 & 1.40 & 0.10 & 0.40 & - & 18.0 \\
\hline 6 & - & - & 0.76 & 0.22 & 0.27 & 0.21 & 0.13 & 0.32 & - & - & - & - & - & - & - \\
\hline 7 & 7.30 & - & 0.88 & 0.09 & 0.88 & 0.50 & 0.22 & 0.05 & 60.0 & 5.00 & 2.00 & 0.50 & - & - & - \\
\hline 8 & 7.78 & 7.05 & 0.78 & 0.73 & 1.19 & 0.59 & 0.28 & 0.21 & 73.0 & 9.32 & 5.88 & 2.04 & 1.62 & - & 175.0 \\
\hline $9 * *$ & 6.10 & 5.15 & - & - & 0.63 & 0.29 & 0.18 & 0.32 & - & - & - & - & - & $1,152.1$ & - \\
\hline 10 & - & - & 0.40 & 0.32 & 0.68 & 0.38 & 0.17 & 0.12 & 44.4 & 5.28 & 2.38 & 1.06 & - & - & 60.0 \\
\hline $11^{* *}$ & 6.37 & 3.10 & - & - & 0.41 & 0.14 & 0.11 & 0.06 & - & - & - & - & - & 0.78 & 96.1 \\
\hline 12 & - & - & 0.72 & 0.04 & 0.50 & 0.20 & 0.12 & 0.39 & 77.0 & 10.0 & 16.00 & 6.0 & 4.0 & - & 81.0 \\
\hline $13^{* *}$ & 7.28 & 15.90 & - & - & 1.87 & 0.38 & 0.35 & 0.22 & - & - & - & - & - & $4,472.7$ & $1,569.3$ \\
\hline
\end{tabular}


Among the macronutrients, the highest variation in the Vairo biofertilizer occurred with the magnesium, with amplitude between 0.01 and $2.60 \mathrm{~g} \mathrm{~L}^{-1}$, referring to an increase of $25,900 \%$ (Table 1), whereas the lowest oscillation occurred with the potassium, with variation from 0.11 to $4.80 \mathrm{~g} \mathrm{~L}^{-1}$, even though with an increase of $4.264 \%$. These variations, also observed for the micronutrients, are partly related to the amount of bovine manner, as well as to the dilutions before the analyses. Aguiar et al. (2017) analyzed and applied the
Vairo biofertilizer in the concentrations of 10,20,30, and $40 \%$ in water, whereas Dias et al. (2011) analyzed the proportion of 1:1 (50\%) in water. However, several authors did not provide information on the dilution before the analysis and application. The mineral nutrients of the dry matter in the Vairo biofertilizer vary significantly. (Table 2). However, the dry matter may represent only $6.5 \%$ in the biofertilizer (Matos et al., 2017) with priority for the soluble components.

Table 2. Mineral constituents in the dry matter of the Vairo biofertilizer.

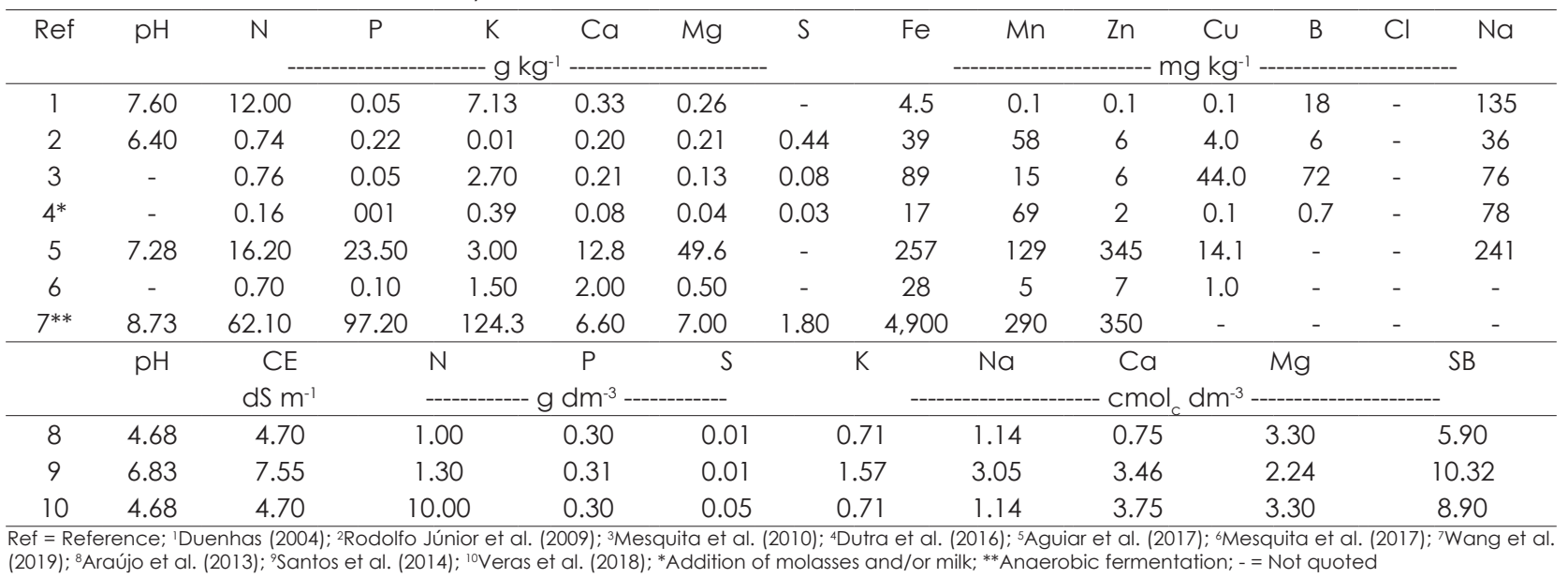

The chemically-enriched biofertilizer also presented a variable constitution in mineral nutrients (Table 3). However, in the literature, only the determinations of dry matter are found, not faithfully representing the concentrations of the present minerals. The Supermagro biofertilizer is cited as an example, whose production employs $1,138.50 \mathrm{~g}$ of sulfur in the form of salts, without considering the sulfur already present in the manure
(Trés \& Resende, 1995). When considering the volumes of water (100 L) and manure (20 L) the concentration of sulfur should be approximately $9.49 \mathrm{~g} \mathrm{~L}^{-1}$ (Trés \& Resende, 1995) whereas in the determination of this macronutrient in the dry matter a maximum of $1.21 \mathrm{~g} \mathrm{~kg}^{-1}$ was obtained (Table 3). This difference is possibly attributed to the dilution of the water content of $89.4 \%$ present in this type of biofertilizer (Silva et al., 2016b).

Table 3. Mineral constituents in the dry matter of chemically-enriched bovine manure biofertilizers.

\begin{tabular}{|c|c|c|c|c|c|c|c|c|c|c|c|c|c|c|c|}
\hline \multirow[t]{2}{*}{ Ref } & $\mathrm{pH}$ & CE & $\mathrm{N}$ & $P$ & K & $\mathrm{Ca}$ & $\mathrm{Mg}$ & S & $\mathrm{Fe}$ & $\mathrm{Mn}$ & $\mathrm{Zn}$ & $\mathrm{Cu}$ & $B$ & $\mathrm{Cl}$ & $\mathrm{Na}$ \\
\hline & & $\mathrm{dS} \mathrm{m}$ & & & $y$ & & & & & & 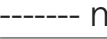 & & & & \\
\hline & \multicolumn{15}{|c|}{ Supermagro } \\
\hline 1 & 5.6 & 4.8 & 1.01 & 0.29 & 0.98 & 0.57 & 0.49 & 1.21 & 148 & 705 & 1,397 & 231 & 471 & - & 382 \\
\hline 2 & 4.6 & 13.2 & 1.43 & 0.26 & 1.01 & 0.49 & 0.26 & 1.07 & 155 & 961 & 1,699 & 332 & 439 & - & 328 \\
\hline 3 & - & - & 2.00 & 0.10 & 3.40 & 5.61 & 1.84 & 0.19 & 62 & 56 & 12 & 23 & 73 & - & 80 \\
\hline 4 & - & - & 0.13 & 0.002 & 0.11 & 0.17 & 0.17 & 0.12 & 5 & 529 & 630 & 149 & 11,929 & - & - \\
\hline \multirow[t]{2}{*}{5} & - & - & 0.70 & 0.10 & 1.20 & 5.90 & 1.70 & 0.50 & 382 & - & 1,410 & 101 & 197 & - & - \\
\hline & \multicolumn{15}{|c|}{ Agrobio } \\
\hline 6 & - & - & 0.48 & 0.18 & 1.33 & 19.2 & 1.31 & 9.39 & 38 & 564 & 177 & 0.9 & 9,675 & & 285 \\
\hline \multicolumn{16}{|c|}{ Agrobom } \\
\hline
\end{tabular}

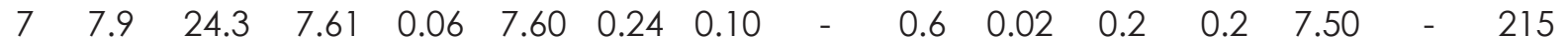
Ref = Reference; 'Rodolfo Júnior et al. (2009); ${ }^{2}$ Rodrigues et al. (2009); ${ }^{3}$ Oliveira et al. (2014); ${ }^{4}$ Lopez et al. (2016); ${ }^{5}$ Silva et al. (2016b); ${ }^{6} \mathrm{Alves}$ et al. (2009); ${ }^{7}$ Duenhas (2004); - = Not quoted

\section{Applications and edaphic effects of the biofertilizer}

The bovine manure biofertilizers are used in plant spraying due to its phytoprotective, hormonal, and nutritional properties, as well as in the treatment of seeds, vegetative propagules, and seedling production (Santos, 1992). They are also used as a nutrient source provided via fertigation, (Duenhas, 2004; Santana et al., 2016; Silva et al., 2016a; Oliveira et al., 2017), as a liquid fertilizer applied 
in the soil (Mesquita et al., 2007; Souza et al., 2016; Aguiar et al., 2017), and as a nutritive solution (Dias et al., 2009). However, either via spraying or directly in the soil, as liquid fertilizer, the dilution of the product after the fermentation is recommended (Santos, 1992; Trés \& Resende, 1995; Fernandes, 2000; Silva et al., 2007a; Aguiar et al., 2017).

The direct effect of the application of bovine manure biofertilizers in the soil is the increase in the availability of nutrients (Alves et al., 2009; Cavalcante et al., 2011 a; Lemes et al., 2013; Oliveira et al., 2014), as a function of the soluble minerals (Tables 1, 2, and 3). In an area cultivated with bell pepper, Alves et al. (2009) concluded that the Vairo and Agrobio biofertilizers raised the $\mathrm{pH}$ and the concentrations of phosphorus, potassium, and soil organic matter, whereas Lemes et al. (2013), while cultivating lettuce, verified that the Vairo biofertilizer raised the contents of calcium and magnesium in the soil. Oliveira et al. (2014) observed increases in phosphorus, potassium, calcium, magnesium, and soil organic matter promoted by the Supermagro, even with superiority to the contents of a soil fertilized with NPK. In the cultivation of yellow passion fruit, Cavalcante et al. (2011b) observed that the Supermagro promoted the increase of boron, copper, and zinc micronutrients in the soil.

Interferences in the microbiological activity and physical properties are the result of an indirect effect of the bovine manure biofertilizer in the soil (Alencar et al., 2018; Wang et al., 2019). In this perspective, Silva et al. (2007b) observed that the increase in the doses of Vairo biofertilizer raised the mineralized carbon in the soi. These authors explain that the microorganisms in the biofertilizer contribute to the conversion of organic compounds in the soil into more labile forms, releasing $\mathrm{CO}_{2}$ and increasing the cycling of carbon and other nutrients.

A wide diversity of bacteria can be found in the biofertilizers, such as acidobacteria, actinobacteria, bacteroidetes, chloroflexi, firmicutes, gemmatimonadetes, proteobacteria, among others (Wang et al., 2019). The application of biofertilizer, such as referred by the authors, increased both the diversity and abundance of bacteria, besides exerting positive effects in the distribution of aggregates in the soil.

In this perspective, Mellek et al. (2010) verified an improvement in the structural quality of the soil with the application of the biofertilizer, such as in the physical attributes of density, macroporosity, mean aggregate diameter, increase in the hydraulic conductivity, and water infiltration. Alencar et al. (2015) also verified an improvement in the water storage and microporosity of a Cambisol treated with the Vairo biofertilizer and cultivated with Ficus carica. A similar situation was registered by Dias et al. (2011) when they concluded that the Vairo biofertilizer decreased the physical resistance of soil under cultivation with yellow passion fruit (Passiflora edulis Sims).

\section{Biofertilizer in the plant}

Phytoprotective action

A sustainable model from the socioeconomic and agro-environmental point of view, which uses processes instead of products in the control of pests and diseases in vegetables, fruits, medicinal and aromatic plants, exerts stability in production with lower financial cost to the producers (Sousa et al., 2012; Sediyama et al., 2014). In this system, the control of pests and diseases is based on the ionic homeostasis (physiological and chemical) of the plant, seeking a greater energy and metabolic balance (entropy) associated to the improvement of the edaphic properties, such as porous space, fertility, increase in the population, and microbiological diversity of the soil (Gondim et al., 2010; Zambolim et al., 2012; Condé et al., 2017).

The biofertilizers exert positive effects in the control of pest insects, mites, and diseases caused by fungi and bacteria. The beneficial effects in the control of diseases are exerted by the presence and action of metabolites produced by the microorganisms present in the organic input and by the direct action of the pathogen on its host (Santos, 1992; Marrocos et al., 2012; Shivlata \& Satyanarayana, 2015).

The potential of the biofertilizer in the phytopathogenic control and on harmful insects occurs due to the action of antibiosis, by the antibiotics in its composition, and by the microbial competition in the soil associated with a resistance induction to the vegetal (Rampelotto et al., 2013). The biofertilizers also contain in their composition volatile substances, such as alcohols, terpene hydrocarbons aldehydes, ketones, phenols, and esters, substances that exert repellent or inhibitory effects and chase away harmful agents to the productive capacity of horticultural crops, as well as reducing the viability of eggs of some pests, such as mites (Medeiros et al., 2003; Fernandes \& Favero, 2014).

Bovine manure biofertilizers possess bioactive compounds formed from the fermentation of organic substances, such as living or static cells of microorganisms, such as bacteria, yeasts, algae, and filamentous fungi, and by its metabolites and organomineral chelates (Lanna Filho et al., 2010; Bhattacharjee \& Dey, 2014). Biofertilizers are also rich in enzymes, antibiotics, 
vitamins, toxins, phenols, esters, and acids, also in the phytohormonal action, in which they exert a resistanceinducing action to the plants, and present fungicidal, bacteriostatic, repellent, insecticidal, and acaricidal properties on several insects and pathogens (Rampelotto et al., 2013; Ghosh et al., 2015).

\section{Insecticidal action}

The action of the bovine biofertilizer on insects is of a repellent nature and/or by potentializing the resistance of the plants, due to volatile substances such as alkaloids, phenols, and esters, through the nutritional balance of the plants, via trophobiosis (Chaboussou, 2012; Fernandes \& Favero, 2014), and through mechanical effect by adhesiveness and anti-dehydration (Gonçalves et al., 2004). In horticultural crops, the biofertilizer has inhibited the presence of pests, reducing the costs with synthetic products (Santos, 1992).

Some studies indicate that bovine manure biofertilizers promote increase of resistance of the plants to pests through the presence of substances, such as waxes and cutin, which contribute to the increase in the cuticle thickness of the leaves, hardening the penetration of the suction tube and, consequently, the injection of toxins by the pest-insect (Popescu et al., 2014; Ahmad ef al., 2015; Doughari, 2015).

Associated to the direct action on pest insects, such as mealybugs (Pseudococcus spp. and Planococcus spp.), caterpillars (Argyrotaenias phaleropa and Spodoptera litura), fruit fly (Anastrepha fraterculus), bugs (Leptoglossus stigma and Orius insidiosus), ande aphids (Brachycaudus schwartzi and Myzus persicae), the bovine biofertilizers also exert antiacaricidal effects. The organic input inhibits the oviposition and viability of the eggs of the reddish black flat mite (Bravipalpus phoenicis) according to the concentration of the input in the spraying of the plants (Medeiros et al., 2003; Fernandes \& Favero, 2014).

\section{Fungicidal and bacteriostatic action}

At the end of the fermentative process, the biofertilizers contained organisms such as Bacillus subtilis. This exerts a function in the biocontrol process of pathogens since it inhibits the growth of fungi and bacteria that cause diseases in the plants (Lanna Filho et al., 2010; Magnabosco, 2010). The bacteria B. subtilis, being a common inhabitant of the soil, establishes itself spontaneously and colonizes the root system zone of the crop, competing with other organisms that especially attack the pathogens Fusarium spp. and Rhizoctonia spp.
This bacterium is also effective in the inhibition of several other pathogenic fungi, among them Sclerotinia spp. and the bacteria Pseudomonas syringae through the production of antifungal and antibacterial metabolites, among them the lipopeptides of the surfactin, iturine, and tengicin families (Flores, 2004; Lanna Filho et al., 2010; Mondal \& Dalai, 2017).

They act in the control of Phytophthora nicotianae through the inhibition of the mycelial growth in Rangpur plants - Citrus limonia (Werh, 2014). Several antagonistic microorganisms to the pathogens were identified, among them thermotolerant bacilliform bacteria, filamentous fungi, and yeast fungi.

Besides the above-mentioned microorganisms, the biofertilizers also possess actinobacteria, which are predominantly gram-positive bacteria in bacillary (Corynebacterium and Arthrobacter) and filamentous form (Streptomyces). These bacteria are associated with the production of antibiotics that contribute to the production of antimicrobials that act defensively against phytopathogens (Rampelotto et al., 2013). Other bacteria of the genus Lactococcus, among them Lactococcus lactis subsp. Lactis and Lactococcus lactis var. maltigenes, are associated to the production of lactic acid and antimicrobial substances such as bacteriocins and hydrogen peroxide, and also antifungal substances that promote an unfavorable environment for the growth and multiplication of pathogens in fruit species (Bettiol et al., 1998; Ghosh et al., 2015).

The bacteriostatic action of the biofertilizer on the population of $X$. campestres pv. Vesicatoria was registered in bell pepper seedlings - Capsicum annuum (Deleito et al., 2004). The authors attributed to the reduction of the infection the complex interaction involving the antibiotic effect of the metabolites produced by the microorganisms of the biofertilizer, the microbial competition of the phylloplane, and nutritional effects to the plants.

\section{Nutritional state and physiology}

The bovine biofertilizer, among other organic inputs, has been used for nutritional supplementation to the horticultural demands. In fruit species, the application is performed via leaf spraying (Marini, 2008), soil (Mesquita et al., 2010; Silva et al., 2016a; Tullio et al., 2018), and also via fertigation (Santana et al., 2016). In vegetable crops, the application directly on the soil is predominant (Nileemas \& Sreenivasa, 2011; Viana et al., 2013; Borges et al., 2014), as well as on the leaves (Oliveira et al., 2014). 
The nutritional state of the plants treated with bovine manure biofertilizer, in macro and micronutrients, was evaluated in several species, and it was verified that the respective input can increase the leaf content of nutrients in horticultural species (Tables 4, 5, and 6).
However, the response of the crops to the biofertilizers varies as a function of factors such as composition, dose, dilution, form, and frequency of application (Marini, 2008; Silva et al., 2016a, 2016b).

Table 4. Contents of macronutrients in leaves of fruit plants without and with application of biofertilizer.

\begin{tabular}{|c|c|c|c|c|c|c|}
\hline Biofertilizer & $\mathrm{N}$ & $P$ & K & $\mathrm{Ca}$ & $\mathrm{Mg}$ & S \\
\hline \multirow{2}{*}{ Without } & \multicolumn{6}{|c|}{ Citrus deliciosa Tenore cv. Rio' } \\
\hline & 24 (d) & $1.71(\mathrm{e})$ & $16.8(a)$ & 16.7 (d) & 4.3 (a) & $2.5(\mathrm{e})$ \\
\hline \multirow[t]{2}{*}{ With** } & 27 (a) & $1.73(e)$ & $18.0(e)$ & 18.0 (d) & 4.3 (a) & $2.5(e)$ \\
\hline & \multicolumn{6}{|c|}{ Carica papaya L. cv. Baixinho de Santa Amália² } \\
\hline Without & $32.85(d)$ & $3.16(d)$ & 23.1 (d) & $11.1(\mathrm{~d})$ & $2.2(d)$ & $2.6(d)$ \\
\hline \multirow[t]{2}{*}{ With * } & $62.93(a)$ & $5.8(a)$ & $31.8(a)$ & 11.1 (d) & 4.1 (d) & 6.3 (a) \\
\hline & \multicolumn{6}{|c|}{ Passiflora edulis L. ${ }^{3}$} \\
\hline Without & $20-39$ (a) & 1.7 (d) & $16-24(d)$ & $18(a)$ & 0.7 (d) & $4-18(e)$ \\
\hline \multirow[t]{2}{*}{ With * } & $30-58$ (a) & $1.8-2.2(d)$ & $10-26(d)$ & $8-24$ (a) & $0.7-1.0(d)$ & $4-18(e)$ \\
\hline & \multicolumn{6}{|c|}{ Ananas comosus L. CV. Pérola ${ }^{4}$} \\
\hline Without & 9.0 (d) & 2.3 (a) & 21.7 (d) & $4.3(\mathrm{e})$ & 2.0 (a) & - \\
\hline \multirow[t]{2}{*}{ With ** } & 8.4 (d) & $2.5(e)$ & 25.0 (a) & 4.0 (a) & 1.9 (d) & - \\
\hline & \multicolumn{6}{|c|}{ Ficus carica L. cv. Roxo de Valinhos ${ }^{5}$} \\
\hline Without & 19.9 (d) & $1.4(a)$ & 14.6 (a) & $35.3(e)$ & $4.5(d)$ & - \\
\hline \multirow{2}{*}{ With * } & $23.1(a)$ & $1.6(a)$ & 17.6 (a) & $43.4(\mathrm{e})$ & 6.0 (a) & - \\
\hline & \multicolumn{6}{|c|}{ Vitis labrusca cv. Niagara Rosada ${ }^{6}$} \\
\hline Without & $23.8(d)$ & $2.9(a)$ & 11.8 (d) & - & - & - \\
\hline With* & $23.8(d)$ & 2.9 (a) & 11.8 (d) & - & - & - \\
\hline
\end{tabular}

The Vairo and Supermagro biofertilizers adequately provided the macronutrient demand of the species C. deliciosa, Carica papaya L., and Ficus carica L. and, therefore, constitute an alternative to the partial and/or total replacement of the synthetic commercial fertilizers (Marini, 2008; Mesquita et al., 2010; Silva et al., 2018). In spite of the high leaf contents of macronutrients in some crops, such as in P. edulis (Cavalcante et al., 2012; Freire et al., 2013), A. comosus (Silva et al., 2016), and V. labrusca (Tullio et al., 2018), the biofertilizer does not replace the synthetic mineral fertilizers.

In vegetable species, biofertilizers also contribute to the increase in the contents of macronutrients (Table 5). However, differently from the fruit species (Table 4), its application even after dilution in the proportion of $1: 1(50 \%)$ in water may cause phytotoxicity due to the excessive content of nutrients, as registered in Capsicum annum L. (Borges et al., 2014), Lycopersicon esculentum (Nileemas \& Sreenivasa, 2011), and Cucumis melo L. (Viana et al., 2013).

Table 5. Contents of macronutrients in leaves of vegetable species without and with bovine manure biofertilizer.

\begin{tabular}{|c|c|c|c|c|c|c|}
\hline Binfertilizer & $\mathrm{N}$ & $P$ & K & $\mathrm{Ca}$ & $\mathrm{Mg}$ & $S$ \\
\hline & \multicolumn{6}{|c|}{ Lycopersicon esculentum Mill cv. Megha' } \\
\hline Without & - & - & - & - & - & - \\
\hline \multirow[t]{2}{*}{ With* } & $19.9(d)$ & $2.4(d)$ & $62(e)$ & - & - & - \\
\hline & \multicolumn{6}{|c|}{ Cucumis melo L. cv. Mirage ${ }^{2}$} \\
\hline Without & $14.3(d)$ & $6.0(e)$ & $5.1(d)$ & - & - & - \\
\hline \multirow[t]{2}{*}{ With** } & $23.2(d)$ & $5.2(e)$ & $23.9(d)$ & - & - & - \\
\hline & \multicolumn{6}{|c|}{ Capsicum annum L. Cv. Sunny $\mathrm{Fl}^{3}$} \\
\hline Without & 20.4 (d) & $4.6(e)$ & 42.9 (e) & - & - & - \\
\hline With*** & 20.8 (d) & $4.1(\mathrm{e})$ & $48.6(e)$ & - & - & - \\
\hline
\end{tabular}

As for the micronutrients, the results with the use of biofertilizers are more similar in the fruit species in comparison with the vegetable crops. Generally, these organic inputs raise the leaf content in fruit species and may attend the nutritional demands (Table 6). In P. edulis, the Vairo biofertilizer attended the need of the plants 
in Fe and Zn (Cavalcante et al., 2008). Besides these nutrients, C. papaya was also supplied in Cu (Mesquita et al., 2010), and A. Comosus only in Cu (Silva et al., 2016b).
With regard to the Supermagro biofertilizer, it supplied the plants of $P$. guajava in B and maintained them deficient in Fe, Mn, and Zn (Santana et al., 2016).

Table 6. Contents of micronutrients in leaves of fruit plants without and with bovine manure biofertilizer.

\begin{tabular}{|c|c|c|c|c|c|}
\hline Biofertilizante & B & $\mathrm{Cu}$ & $\mathrm{Fe}$ & $M n$ & Zn \\
\hline & \multicolumn{5}{|c|}{ Passiflora edulis Sims. ${ }^{1}$} \\
\hline Without & $13.3(d)$ & 18.5 (a) & 77.0 (d) & 14.9 (d) & 10.3 (d) \\
\hline \multirow[t]{2}{*}{ With* } & 30.3 (d) & $93.7(d)$ & 142.0 (a) & 23.3 (d) & 28.6 (a) \\
\hline & \multicolumn{5}{|c|}{ Carica papaya L. cv. Baixinho de Santa Amália ${ }^{2}$} \\
\hline Without & 11.8 (d) & 7.1 (d) & 63.9 (d) & $32.6(d)$ & $21.8(d)$ \\
\hline \multirow[t]{2}{*}{ With* } & $21.8(e)$ & $13.5(a)$ & 133.1 (a) & $57.8(d)$ & 47.0 (a) \\
\hline & \multicolumn{5}{|c|}{ Psidium guajava L. cv. Paluma ${ }^{3}$} \\
\hline Without & $30.8(a)$ & - & 71.7 (d) & $12.1(d)$ & $4.0(d)$ \\
\hline \multirow[t]{2}{*}{ With** } & 30.5 (a) & - & $109.1(d)$ & $14.3(d)$ & 4.5 (d) \\
\hline & \multicolumn{5}{|c|}{ Ananas comosus L. cv. Pérola ${ }^{4}$} \\
\hline Without & - & 3.5 (d) & - & $908.3(e)$ & 19.0 (d) \\
\hline With* & - & 5.7 (a) & - & $971.3(\mathrm{e})$ & 33.0 (d) \\
\hline
\end{tabular}

Scientific data on the effects of the bovine manure biofertilizers in the physiology of horticultural plants are still incipient in the literature. The biofertilizers, for their diversity in mineral and organic elements, act as enzymatic, physiological and metabolic activators in the plants (Mesquita et al., 2014). Among the physiological aspects, biofertilizers have been studied in the synthesis of pigments, (Cavalcante et al., 2011b), chlorophyll fluorescence (Freire et al., 2014), and gas exchange (Viana et al., 2013).

The stimulation in the production of photosynthetic pigments, such as chlorophylls $a, b$, and carotenoids, varies among vegetal species, the source, and the applied concentration of the biofertilizer (Freire et al., 2013; Viana et al., 2013; Lima Neto et al., 2018). The increase in the synthesis of photosynthetic pigments is attributed to the presence of nitrogen and magnesium, which are structural elements of the chlorophylls and carotenoids (Taiz et al., 2017). As for the fluorescence dynamics of the chlorophyll $a$, the biofertilizer stimulated the potential quantum efficiency in $P$. edulis (Freire et al., 2014).

The bovine manure biofertilizer also interferes with the gas exchanges of horticultural plants. In vegetable species such as C. melo, the effects are associated to the type (Viana et al., 2013); in Beta vulgaris to the fermentation period (Oliveira Neto et al., 2017); and in C. annuum to the doses of biofertilizer (Borges et al., 2014). In plants of $P$. edulis, the biofertilizer raised the internal concentration of $\mathrm{CO}_{2}$ and reduced the stomatal conductance and transpiration, without interfering in the liquid assimilation of carbon dioxide (Freire et al., 2014).

\section{Biofertilization in production and physical and physico-chemical quality of horticultural species}

For a long time, biofertilizers have been used as a relevant alternative in the production of horticultural species in Brazil (Santos, 1992; Mesquita et al., 2007; Nunes et al., 2018) in order to decrease the indiscriminate use of synthetic mineral fertilizers, which raise the production cost and, in some cases, induce environmental degradation (Pinheiro \& Barreto, 1996; Rocha et al., 2013; Mahanty et al., 2017).

There is information in the literature that justifies the employment of biofertilization of the fermented bovine manure in horticultural crops (Table 7). In fruit crops, the application of biofertilizers supplanted in $43,88,96$, and $122 \%$ the yield of $P$. guajava (Santana et al., 2017), F. carica (Silva et al., 2016a), C. papaya (Mesquita et al., 2007), and $P$. edulis (Aguiar et al., 2017), respectively. In vegetable crops, increments of 21, 23, 31 , 72,95 , and $344 \%$ were noted in the crops of Abelmos chusesculentus (Nunes et al., 2018), Allium cepa (Nobile et al., 2013) Ipomoea batatas (Oliveira et al., 2007), C. bacatum (Oliveira et al., 2014), Dioscorea cayennensis (Silva et al., 2012), and Citrullus lanatus (Dutra et al., 2016), respectively.

The effects of the biofertilizers on the yield of horticultural crops are attached to several factors, among them the composition, preparation, forms of use, dilutions and frequency of application, among others, with differentiated responses among crops. Mesquita et al. (2007) cultivated C. papaya in soil with Vairo and Supermagro biofertilizer and obtained maximum yields 
of 53.6 and $50.9 \mathrm{tha}^{-1}$, respectively, with a reduction of $5 \%$ in Supermagro in relation to the Vairo. Araújo et al. (2013) also observed that the mean fruit mass of Musa acuminata varied as a function of the bovine manure biofertilizers.

With regard to the application form, Silva et al. (2012) registered a yield increase in Dioscorea cayennensis with the Vairo biofertilizer provided via soil and leaves. Dilution effects of the biofertilizer in the yield of horticultural crops can also be found in the literature, such as in Fragaria $X$ ananassa (Mazaro et al., 2013), F. carica (Silva et al., 2016a), and P. edulis (Aguiar et al., 2017). Differences are also registered as to the frequency of application, such as in C. Papaya, with the biofertilizer applied every 60 days after planting, (Mesquita et al., 2007) and in $P$. edulis under a monthly frequency (Aguiar et al., 2017).

The responses of the biofertilizer are also differentiated concerning both the species and the cultivar. As registered in C. Papaya, in which the highest yield was achieved with the application of 1.6 L per groove of Vairo biofertilizer, (Mesquita et al., 2007), whereas in $P$. edulis, the volume of $2 \mathrm{~L}$ per groove did not reach the maximum productive potential of the crop (Aguiar et al., 2017). These authors also registered distinct responses of the biofertilizer among the cultivars of $P$. edulis, with yields of 15.0, 12.5, and $3.4 \mathrm{tha}^{-1}$, respectively, for the genotypes Gigante Amarelo (BRS GA 1), local accession, and Sol do Cerrado (BRS SC1). The effect of this organic input may be potentialized with the application of synthetic fertilizer or even to partly reduce the dependency. Santana et al. (2016) recommend the application of the biofertilizer even with the recommended supplementation of nitrogen for the crop of $P$. guajava.

The increase in production does not always imply the physical and physico-chemical quality of the fruits. In this context, studies show responses of the biofertilizers whose effects are associated with the crop and quality attributes (Table 8). In the physical attributes, it was observed that the biofertilizer increases the firmness of fruits in C. papaya (Mesquita et al., 2007) and P. guajava (Santana et al., 2017), and the pulp yield in $P$. edulis (Rocha et al., 2013; Aguiar et al., 2017). As for the physicochemical attributes, the biofertilizer raises the pulp $\mathrm{pH}$ M. acuminata (Santos et al., 2014), C. lanatus (Dutra et al., 2016), P. guajava (Santana et al., 2017) and P. edulis (Aguiar et al., 2017).

The titratable acidity of the pulp in C. papaya (Mesquita et al., 2007), V. labrusca (Gomes et al., 2013), and $P$. edulis (Rocha et al., 2013; Aguiar et al., 2017) was raised with the use of biofertilizers, countering the reduction in P. guajava (Santana et al. 2017). In the soluble solids, an increase was only observed in the presence of biofertilizer (Table 8). As for the sweetness, expressed by the relation between soluble solids and titratable acidity, it was increased in the fruits of $\mathrm{V}$. labrusca (Gomes et al., 2013), P. edulis (Aguiar et al., 2017). The content of vitamin $C$ with the use of biofertilizer was also raised in $P$. guajava (Santana et al., 2017) and P. edulis (Aguiar et al., 2017).

It is worth noting that the effect of the biofertilizer on the physical and physico-chemical properties of fruits, such as the yield, depends on the type and dose of bovine manure biofertilizer (Gomes et al., 2013; Santos et al., 2014). The effects are also associated with the doses and genotypes, as presented by Aguiar et al. (2017), who evaluated three genotypes of $P$. edulis.

Table 7. Yield $\left(t h a^{-1}\right)$ and mean fruit mass - MMF (g) of fruit and vegetable crops without and with bovine manure biofertilizer, and the increase (I\%) promoted by this organic input.

\begin{tabular}{|c|c|c|c|c|c|c|c|}
\hline \multirow{2}{*}{ Horticultural species } & \multicolumn{3}{|c|}{ Yield } & \multicolumn{3}{|c|}{ MMF } & \multirow{2}{*}{ References } \\
\hline & Without & With & 1 & Without & With & I & \\
\hline \multicolumn{8}{|c|}{ Fruit species } \\
\hline Carica papaya L. & 28.5 & 53.6 & 88 & 424.7 & 476.3 & 12 & Mesquita et al. (2007) \\
\hline Musa acuminata & - & - & - & 191.9 & 240.0 & 25 & Araújo et al. (2013) \\
\hline Fragaria $X$ ananassa & - & - & - & 13.1 & 16.6 & 27 & Mazaro et al. (2013) \\
\hline Ficus carica L. & 6.6 & 12.9 & 96 & 56.9 & 77.2 & 28 & Silva et al. (2016a) \\
\hline Psidium guajava & 18.6 & 26.6 & 43 & - & - & - & Santana et al. (2017) \\
\hline Passiflora edulis Sims & 6.8 & 14.9 & 122 & 214.5 & 326.2 & 52 & Aguiar et al. (2017) \\
\hline Vitis labrusca & - & - & - & 1.3 & 2.0 & 52 & Lima et al. (2018) \\
\hline \multicolumn{8}{|c|}{ Vegetable species } \\
\hline Ipomoea batatas $L$. & 7.1 & 93 & 31 & 177.1 & 267.4 & 51 & Oliveira et al. (2007) \\
\hline Allium cepa $\mathrm{L}$. & 17.7 & 21.7 & 23 & 90.0 & 104.1 & 16 & Nobile et al. (2012) \\
\hline Dioscorea cayennensis & 8.9 & 17.4 & 95 & 1,181 & 1,351 & 14 & Silva et al. (2012) \\
\hline Capsicum annuum & - & - & - & 71.7 & 75.1 & 5 & Lima Neto et al. (2013) \\
\hline Lactuca sativa L. & - & - & - & 195.8 & 308.2 & 57 & Chiconato et al. (2014) \\
\hline Capsicum bacatum & 8.9 & 15.5 & 72 & 4.62 & 5.36 & 16 & Oliveira et al. (2014) \\
\hline Citrullus lanatus & 28 & 124 & 344 & - & - & - & Dutra et al. (2016) \\
\hline Abelmoschus esculentus & 14.7 & 17.8 & 21 & 19.3 & 19.5 & 1 & Nunes et al. (2018) \\
\hline
\end{tabular}


Table 8. Firmness, pulp yield (PY), pH, titratable acidity (TA), soluble solids (SS), and vitamin C (VC) of fruit and vegetable species without and with the application of bovine manure biofertilizer.

\begin{tabular}{|c|c|c|c|c|c|c|c|c|}
\hline Biofertilizer & $\begin{array}{c}\text { Firmness } \\
(\mathrm{N})\end{array}$ & $\begin{array}{l}\text { PY } \\
(\%)\end{array}$ & $\begin{array}{r}\mathrm{pH} \\
- \\
\end{array}$ & $\begin{array}{l}\text { TA } \\
\% \\
\end{array}$ & $\begin{array}{c}\text { SS } \\
\left({ }^{\circ} \text { Brix) }\right.\end{array}$ & $\begin{array}{c}\text { SS/TA } \\
- \\
\end{array}$ & VC & Reference \\
\hline \multicolumn{9}{|c|}{ Carica papaya $L$. } \\
\hline Without & 22.77 & 65.9 & 5.40 & 4.20 & 12.00 & 2.98 & - & Mesquita et al. (2007) \\
\hline \multicolumn{9}{|c|}{ Vitis labrusca } \\
\hline Without & - & - & - & 3.15 & 18.95 & 6.02 & - & Gomes et al. (2013) \\
\hline \multicolumn{9}{|c|}{ Musa acuminata } \\
\hline Without & - & - & 4.81 & - & 15.31 & - & - & Santos et al. (2014) \\
\hline \multicolumn{9}{|c|}{ Citrullus lanatus } \\
\hline Without & - & - & 5.50 & - & 7.64 & - & - & Dutra et al. (2016) \\
\hline \multicolumn{9}{|c|}{ Psidium guajava } \\
\hline Without & 43.90 & - & 4.30 & 0.51 & - & - & $77.08^{1}$ & Santana et al. (2017) \\
\hline \multicolumn{9}{|c|}{ Passiflora edulis Sims } \\
\hline Without & - & 62.84 & 2.75 & 5.65 & 11.44 & 2.02 & $24.92^{2}$ & Aguiar et al. (2017) \\
\hline With & - & 63.78 & 2.82 & 6.13 & 13.73 & 2.24 & $26.30^{2}$ & \\
\hline
\end{tabular}

'mg 100 ${ }^{-1},{ }^{2} \mathrm{~g} 100 \mathrm{~mL}^{-1}$ of ascorbic acid; - = Not quoted.

\section{Conclusions}

The bovine manure biofertilizers exert effects on the soil and plants that are associated with its composition. In the soil, the effects are of physical, chemical, and biological nature; in the plants, they exert actions in the phytosanitary control, mineral nutrition, and physiology, with effects also on the components of production and post-harvest quality of horticultural crops.

In Brazil, the Vairo, Supermagro, Agrobio, and Agrobom bovine manure biofertilizers are predominant, with the first one, also known as common biofertilizer, being the most used. When considering the biodynamic aspects in agriculture, there is a need for a greater variety of organic inputs, increasing the portfolio of use of natural resources. For comparison between biofertilizers, the chemical characterization of the soluble constituents must be performed.

The effects of the bovine manure biofertilizers are more often observed on the yield and leaf content of essential nutrients than in the physiological, biochemical, and physical and physico-chemical quality of production in horticultural crops. Even with the confirmation of bioactive compounds in the bovine manure biofertilizers and the reports of their effects in phytoprotection, there is a need for greater investment in scientific studies to corroborate the positive action of such organic inputs in the soils and plants.

\section{References}

Aguiar, A.V.M., Cavalcante, L.F., Salva, R.M., Dantas, T.A.G., Santos, E.C. 2017. Effect of biofertilization on yellow passion fruit production and fruit quality. Revista Caatinga
30: 136-148.

Ahmad, H.M., Rahman, M.U., Ali, Q., Awan, S.I. 2015. Plant cuticular waxes: a review on functions, composition, biosyntheses mechanism and transportation. Life Science Journal 12: 60-67.

Alencar, T.L., Chaves, A.F., Santos, C.L.A., Assis Júnior, R.N., Mota, J.C.A. 2015. Atributos físicos de um Cambissolo cultivado e tratado com biofertilizante na Chapada do Apodi, Ceará. Revista Brasileira de Ciência do Solo 39: 737-749.

Alencar, T.L., Sousa, L.F.R.A., Chaves, A.F., Mota, J.C.A. 2018. Response function for the $S_{\text {relative }}$ index in Cambisol treated with and without bovine liquid biofertilizer. Revista Caatinga 31: 466-475.

Alves, G.S., Nascimento, J.A.M., Santos, D., Alves, S.S.V., Silva, J.A. 2009. Fertilidade do solo cultivado com pimentão sob aplicação de diferentes tipos de biofertilizantes. Revista Verde de Agroecologia e Desenvolvimento Sustentável 4: 33-41.

Alves, S.B., Medeiros, M.B., Tamai, M.A., Lopes, R.B. 2001. Trofobiose e microrganismos na proteção de plantas: biofertilizantes e entomopatógenos na citricultura orgânica. Biotecnologia Ciência \& Desenvolvimento 21: 16-21.

Araújo, J.F. 2010. Biofertilizantes líquidos. Franciscana, Juazeiro, Brasil. $118 \mathrm{p}$.

Araújo, J.S.S., Medeiros, A.S., Campo, A.C., Alves, F.I., Abrantes, E.G., Santos, J.G.R. 2013. Produção da bananeira nanica ( $1^{\circ}$ ciclo) em função da aplicação de doses de biofertilizantes líquidos. Revista Verde de Agroecologia e Desenvolvimento Sustentável 8: 101-115.

Bettiol, W., Tratch, R., Galvão, J.A.H. 1998. Controle de doenças de plantas com biofertilizantes. Embrapa- 
CNPMA, Jaguariúna, Brasil. 22 p.

Bhattacharjee, R., Dey, U. 2014. Biofertilizer, a way towards organic agriculture: a review. African Journal of Microbiology Research 8: 2332-2342.

Borges, F.R.M., Viana, T.V.A., Marinho, A.B., Pinheiro Neto, L.G., Azevedo, B.M. 2014. Gas exchange and leaf contents in bell pepper under energized water and biofertilizer doses. Revista Brasileira de Engenharia Agrícola e Ambiental 20: 533-538.

Brasil. Decreto $n^{\circ}$ 4.954, de 14 de Janeiro de 2004. 2004. http://www.planalto.gov.br/ccivil_03/_Ato20042006/2004/Decreto/D4954.htm <Acesso 01 Fev. 2019>

Cavalcante, L.F., Cavalcante, I.H.L., Rodolfo Júnior, F., Beckmann-Cavalcante, M.Z., Santos, G.P. 2012. Leafmacronutrient status and fruit yield of biofertilized yellow passion fruit plants. Journal of Plant Nutrition 35: 176-191.

Cavalcante, L.F., Cavalcante, I.H.L., Santos, G.D. 2008. Micronutrient and sodium foliar contents of yellow passion plants as a function of biofertilizers. Fruits 63: 27-36.

Cavalcante, L.F., Dias, T.J., Nascimento, R., Freire, J.L.O. $2011 b$. Clorofila e carotenoides em maracujazeiroamarelo irrigado com águas salinas no solo com biofertilizante bovino. Revista Brasileira de Fruticultura especial: 699-705.

Cavalcante, L.F., Rodrigues, A.C., Diniz, A.A., Fernandes, P.D., Nascimento, J.A.M., Oliveira, F.A. 2011 . Micronutrientes e sódio num solo cultivado com maracujazeiro amarelo, com a aplicação de biofertilizante supermagro e potássio. Revista Brasileira de Ciências Agrárias 6: 376-382.

Chaboussou, F. 2012. Plantas doentes pelo uso de agrotóxicos: novas bases de uma prevenção contra doenças e parasitas - a teoria da trofobiose. Expressão Popular, São Paulo, Brasil. 318 p.

Chiconato, D.A., Galbiatti, J.A., Maldonado Junior, W., Franco, C.F., Caramelo, A.D. 2014. Bovine biofertilizer and irrigation layers on lettuce development and leaf chorophyll. Comunicata Scientiae 5: 140-147.

Chiconato, D.A., Simoni, F., Galbiatti, J.A., Franco, C.F., Caramelo, A.D. 2013. Resposta da alface à aplicação de biofertilizante sob dois níveis de irrigação. Bioscience Journal 29: 392-399.

Condé, V.F., Oliveira, D.M.F., Oliveira, J.E.Z. 2017. Incidência e severidade de hérnia das crucíferas em repolho (Brassica oleracea L. var. capitata) em solo tratado com biofertilizante tipo Bokashi. Ciência e Natura 39: 7-15.

Deleito, C.S.R., Carmo, M.G.F., Fernandes, M.C.A., Abboud, A.C.S. 2004. Biofertilizante agrobio: uma alternativa no controle da mancha bacteriana em mudas de pimentão (Capsicum annuum L.). Ciência Rural 34: 1035-1038.

Dias, N.S., Brito, A.A.F., Sousa Neto, O.N., Lira, R.B., Brito, R.F. 2009. Produção de alface hidropônico utilizando biofertilizante como solução nutritiva. Revista Caatinga 22: 158-162.

Dias. T.J., Cavalcante, L.F., Leon, M.J., Santos, G.P., Albuquerque, R.P.F. 2011. Produção do maracujazeiro e resistência mecânica do solo com biofertilizante sob irrigação com águas salinas. Revista Ciência Agronômica 42: 644-651.

Doughari, J.H. 2015. An overview of plant immunity. Journal of Plant Pathology and Microbiology 11:1-11.

Duenhas, L.H. 2004. Cultivo orgânico do melão: aplicação de esterco e de biofertilizantes e substâncias húmicas via fertirrigação. 90f. (Tese de Doutorado) - Universidade de São Paulo, Piracicaba, Brasil.

Dutra, K.O.G., Cavalcante, S.N., Vieira, I.G.S., Costa, J.C.F., Andrade, R. 2016. A adubação orgânica no cultivo da melancieira cv. Crimson Sweet. Revista Brasileira de Agropecuária Sustentável 6: 34-45.

Fernandes, E.T., Favero, S. 2014. Óleo essencial de Schinus molle L. para o controle de Sitophilus zeamais Most.1855 (Coleoptera: Curculionidae) em milho. Revista Brasileira de Agroecologia 9:225-231.

Fernandes, M.C.A. 2000. O biofertilizante Agrobio. Embrapa Agrobiologia, São Paulo, Brasil. 2 p. (Série Agricultura Orgânica, ano 4, n. 13).

Flores, R.F. 2004. Evaluacion in vitro del control de Bacillus sp. sobre Clavibacter michigaensis subsp. Michigaensis. 70f. (Dissertação de Graduação) - Universidade de Talca, Talca, Chile.

Freire, J.L., Dias, T.J., Cavalcante, L.F., Fernandes, P.D., Lima Neto, A.J. 2014. Rendimento quântico e trocas gasosas em maracujazeiro amarelo sob salinidade hídrica, biofertilização e cobertura morta. Revista Ciência Agronômica 45: 82-91.

Freire, J.L.O., Cavalcante, L.F., Nascimento, R., Rebequi, A. M. 2013. Teores de clorofila e composição mineral foliar do maracujazeiro irrigado com águas salinas e biofertilizante. Revista de Ciências Agrárias 36: 57-70.

Ghosh, R., Mukhopadhyay, A., Mandal, N.C. 2015. Biological control of fruit-rot of jackfruit by rhizobacteria and food grade lactic acid bacteria. Biological Control 83: 29-36.

Gomes, A.T., Nascimento, O.S., Medeiros, A.S., Alves, F.I.S., Santos, J.G.R. 2013. Estudo dos efeitos de diferentes tipos e doses de biofertilizantes na produção e qualidade da produção da videira "Isabel". Revista Verde de Agroecologia e Desenvolvimento Sustentável 8: 244-252.

Gonçalves, M.M., Schiedeck, G., Schwengber, J.E. 2009. Produção e uso de biofertilizantes em sistemas de produção de base ecológica. Embrapa Clima Temperado, Pelotas, Brasil. 7 p. (Circular Técnica, 78).

Gonçalves, P.A.S., Werner, H., Debarba, J. F. 2004. Avaliação de biofertilizantes, extratos vegetais e diferentes substâncias alternativas no manejo de tripés em cebola em sistema orgânico. Horticultura Brasileira 


\section{2: $659-662$}

Gondim, S.C., Souto, J.S., Cavalcante, L.F., Rodrigues, K.M.Q. 2010. Biofertilizante bovino e salinidade da água na macrofauna do solo cultivado com maracujazeiro amarelo. Revista Verde de Agroecologia e Desenvolvimento Sustentável 5: 35-45.

Lanna Filho, R., Ferro, H.M., Pinho, R.S.C. 2010. Controle biológico mediado por Bacillus subtilis. Revista Trópica: Ciências Agrárias e Biológicas 4: 12-20.

Lemes, R.L., Soares Filho, C.V., Garcia Neto, M., Heinrichs, 2013. The chemical properties of soil for alfalfa production after biofertiliser application. Semina: Ciências Agrárias 34: $2211-2218$.

Leonel, S., Araújo, J.F., Tecchio, M.A. 2015. Biofertilização e adubação organomineral: concentração de nutrientes na folha e produtividade de frutos de pinheira. Irriga 20: 40-51.

Lima, A.S., Silva, F.L., Santos, J.M., Santos, J.G.R., Alves, J.M., Sousa, C.S. 2018. Produção da videira 'Isabel' em função de tipos e doses de biofertilizantes. Revista Agropecuária Técnica 39: 238-245.

Lima Neto, A.J., Cavalcante, L.F., Nunes, J.C., Souto, A.G.L., Bezerra, F.T.C., Cavalcante, A.G. 2018. Biometric variables and photosynthetic pigments in tamarind seedlings irrigated with saline water and biofertilizers. Semina: Ciências Agrárias 39: 1909-1920.

Lima Neto, A.J., Dantas, T.A.G., Cavalcante, L.F., Dias, T.J., Diniz, A.A. 2013. Biofertilizante bovino, cobertura morta e revestimento lateral dos sulcos na produção de pimentão. Revista Caatinga 26: 1-8.

Lopez, M.A.R., Junqueira, A.M.R., Mejia, L.M. 2016. Estabilidade do biofertilizante Supermagro. Revista Brasileira de Agroecologia 11: 152-156.

Magnabosco, M.C. 2010. Avaliação da eficiência da calda bordalesa, da calda sulfocálcica e do biofertilizante supermagro no cultivo orgânico de morangueiro. 92f. (Dissertação de Mestrado) - Universidade Tecnológica Federal do Paraná, Pato Branco, Brasil.

Mahanty, T., Bhattacharjee, S., Goswami, M., Bhattacharyya, P., Das, B., Ghosh, A., Tribedi, P. 2017. Biofertilizers: a potential approach for sustainable agriculture development. Environmental Science and Pollution Research 24: 3315-3335.

Malavolta, E., Vitti, G.C., Oliveira, S.A. 1997. Avaliação do estado nutricional das plantas: princípios e aplicações. Potafos, Piracicaba, Brasil. 319 p.

Mangalassery, S., Kalaivanan, D., Philip, P.S. 2019. Effect of inorganic fertilizers and organic amendments on soil aggregation and biochemical characteristics in a weathered tropical soil. Soil \& Tillage Research 187: 144151.

Marini, F.S. 2008. Fertilizantes alternativos no manejo da mexeriqueira 'Rio' no sistema de cultivo orgânico. 109f. (Tese de Doutorado) - Universidade Estadual do Norte
Fluminense Darcy Ribeiro, Campos dos Goytacazes, Brasil.

Marrocos, S.T.P., Novo Junior, J., Granjeiro, L.C., Ambrosio, M.M.Q., Cunha, A.P.A. 2012. Composição química e microbiológica de biofertilizantes em diferentes tempos de decomposição. Revista Caatinga 25: 34-4.

Matos, C.F., Pinheiro, E.F.M., Paes, J.L., Lima, E., Campos, D.V.B. 2017. Avaliação do potencial de uso de biofertilizante de esterco bovino resultante do sistema de manejo orgânico e convencional da produção leiteira. Revista Virtual de Química 9: 1957-1669.

Mazaro, S.M., Mangnabosco, M.C., Citadin, I., Paulus, D., Gouvea, A. 2013. Produção e qualidade de morangueiro sob diferentes concentrações de calda bordalesa, sulfocálcica e biofertilizante supermagro. Semina: Ciências Agrárias 34: 3285-3294.

Medeiros, M.B. de, Wanderley, P.A., Wanderley, M.J.A. 2003. Biofertilizantes líquidos. Revista Biotecnologia, Ciência \& Desenvolvimento31: 38-44.

Mellek, J.E., Dieckow, J., Silva, V.L., Favaretto, N., Pauletti, V., Vezzani, F.M., Souza, J.L.M. 2010. Dairy liquid manure and no-tillage: physical and hydraulic properties and carbon stocks in a Cambisol of Southern Brazil. Soil \& Tillage Research 110: 69-76.

Mesquita, E.F., Cavalcante, L.F., Gondim, S.C., Campos, V.B., Cavalcante, I.H.L., Gondim, P.C. 2010. Teores foliares e exportação de nutrientes do mamoeiro baixinho de Santa Amália tratado com biofertilizantes. Pesquisa Agropecuária Tropical 40: 66-76.

Mesquita, E.F., Cavalcante, L.F., Gondim, S.C., Cavalcante, I.H.L., Araújo, F.A.R., Beckmann-Cavalcante, M.Z. 2007. Produtividade e qualidade de frutos do mamoeiro em função de tipos e doses de biofertilizantes. Semina: Ciências Agrárias 28: 589-596.

Mesquita, S.B.S., Costa, R.S., Amorim, A.V., Lacerda, C.F., Fonseca, A.M. 2017. Crescimento e composição do óleo essencial de malvariço cultivado sob salinidade e doses de biofertilizante. Revista Agro@mbiente 11:315-322.

Mesquita, S.B.S., Silva, J.A., Costa, R.S., Santos, M.W.N., Lacerda, C.F., Amorim, A.V., Bezerra, A.M.E. 2014. Gas exchange and growth of medicinal plant subjected to salinity and application of biofertilizers. American Journal of Plant Sciences 5: 2520-2527.

Mondal, P., Dalai, A.K. 2017. Sustainable utilization of natural resources. Taylor \& Francis Group, Boca Raton, United States. $624 \mathrm{p}$.

Nascimento, J.A.M., Cavalcante, L.F., Dantas, S.A.G., Medeiros, S.A.S., Dias, T.J. 2015. Biofertilizante e adubação mineral na qualidade de frutos de maracujazeiro irrigado com água salina. Irriga 20: 220-232.

Nileemas, G., Sreenivasa, M.N. 2011. Influence of liquid organic manures on growth, nutrient content and yield of tomato (Lycopersicon esculentum Mill.) in the sterilized soil. Karnataka Journal of Agricultural Sciences 24: 153157. 
Nobile, F.O., Galbiatti, A.J., Muraishi, R.I., Spadoni, T.B. 2012. Biofertilizante e adubação mineral no desenvolvimento da cultura da cebola (Allium cepa L.) irrigado com duas lâminas de água. Nucleus 9: 27-34.

Nunes, J.A.S., Nunes, J.C., Silva, J.A., Oliveira. A.P., Cavalcante, L.F., Oresca, D., Silva, O.P.R. 2018. Influence of spacing and application of biofertilizer on growth and yield of okra (Abelmoschus esculentus (L.) Moe-h). African Journal of Biotechnology 17: 17-23.

Oliveira, A.P., Barbosa, A.H.D., Cavalcante, L.F., Pereira, W.E., Oliveira, A.N.P. 2007. Produção da batata-doce adubada com esterco bovino e biofertilizante. Ciência \& Agrotecnologia 31: 1722-1728.

Oliveira, A.P., Oliveira, A.N., Silva, O.P.R., Pinheiro, S.M. Gomes Neto, A.D. 2013. Rendimento do quiabo adubado com esterco bovino e biofertilizante. Semina: Ciências Agrárias 34: 2629-2636.

Oliveira, F.I.F., Medeiros, W.J.F., Cavalcante, L.F., Cavalcante, I.H.L., Souto, A.G.L., Lima Neto, A.J. 2017. Crescimento e produção do maracujazeiro amarelo fertirrigado com esterco bovino líquido fermentado. Revista Agropecuária Técnica 38: 191-199.

Oliveira, J.R., Gomes, R.L.F., Araújo, A.S.F., Marini, F.S., Lopes, J.B., Araújo, R.M. 2014. Estado nutricional e produção da pimenteira com uso de biofertilizantes líquidos. Revista Brasileira de Engenharia Agrícola e Ambiental 18: 1241-1246.

Oliveira Neto, H.T., Gondim, A.R.O., Sá, F.V.S., Souto, L.S., Brito, M.E.B., Silva, M.S., Lira, R.P. 2017. Growth, gas exchanges and production of beet $\mathrm{CV}$. Katrina under organo-mineral fertilization. Bioscience Journal 33: 11261133.

Pinheiro, S., Barreto, S.B. 1996. MB-4: agricultura sustentável, trofobiose e biofertilizantes. Fundação Juquira Candiru/ Mibasa, Florianópolis, Brasil. 273 p.

Popescu, C., Pruteanu, A., Voicea, I., Ivancu, B., Găgeanu, G., Popa, L. Vlădut, V. 2014. Study regarding biochemica characterization and some preparations from nettle and wormwood in order to capitalize them as bioinsecticide/ biofertilizers in organic agriculture. Analele Universității din Craiova 44: 175-185.

Rampelotto, P.H., Ferreira, A.S., Barboza, A.D.M., Roesch, L.F.W. 2013. Changes in diversity, abundance, and structure of soil bacterial communities in Brazilian savanna under different land use systems. Microbial Ecology 66: 593-607.

Rocha, L.F., Cunha, M.S., Santos, E.M., Lima, F.N., Mancin, A.C., Cavalcante, I.H.L. 2013. Biofertilizante, calagem e adubação com NK nas características físicas e químicas de frutos de maracujazeiro-amarelo. Revista Brasileira de Ciências Agrárias 8: 555-562.

Rodolfo Junior, F., Cavalcante, L.F., Buriti, E.S. 2009. Crescimento e produção do maracujazeiro-amarelo em solo com biofertilizantes e adubação mineral com NPK. Revista Caatinga 22: 149-160.
Rodrigues, A.C., Cavalcante, L.F., Oliveira, A.P., Sousa, J.T., Mesquita, F.O. 2009. Produção e nutrição mineral do maracujazeiro-amarelo em solo com biofertilizante supermagro e potássio. Revista Brasileira de Engenharia Agrícola e Ambiental 13: 117-124.

Sambuichi, R.H.S., Oliveira, M.A.C., Silva, A.P.M., Luedemann, G. 2012. A sustentabilidade ambiental da agropecuária brasileira: impactos, políticas públicas e desafios. Ipea, Rio de Janeiro, Brasil. 46 p.

Santana, E.A., Cavalcante, I.H.L., Brito, D.S., Carmo, R.N., Sousa, K.S.M. 2017. Fruit production and quality of guava as a function of biofertilizer and nitrogen fertigation in Brazilian semiarid. Emirates Journal of Food and Agriculture 29: 242-249.

Santana, E.A., Lobo, J.T., Pereira, R.N., Lima, A.M.N., Cunha, J.C., Cavalcante, I.H.L. 2016. Micronutrientes foliares na goiabeira fertirrigada com biofertilizante e nitrogênio no semiárido. Comunicata Scientiae 7: 523527.

Santos, A.C.V. 1992. Biofertilizante líquido: o defensivo agrícola da natureza. Emater-Rio, Niterói, Brasil. 16 p.

Santos, A.C.V., Akiba, F. 1996. Biofertilizante líquido: uso correto na agricultura alternativa. Imprensa Universitária UFRRJ, Seropédica, Brasil. 35 p.

Santos, J.G.R., Andrade, R., Galdino, P.O., Linhares, A.S.F., Maia, P.M.E., Lima, A.S. 2014. Qualidade da produção da bananeira Nanicão em função do uso de biofertilizantes. Revista Brasileira de Engenharia Agrícola e Ambiental 18: 387-393.

Sediyama, M.A.N., Santos, I.C., Lima, P.C. 2014. Cultivo de hortaliças no sistema orgânico. Revista Ceres 61: 829-837.

Shivlata, L., Satyanarayana, T. 2015. Thermophilic and alkaliphilic Actinobacteria: biology and potential applications. Frontiers in Microbiology 6: 1-29.

Silva, A.F., Pinto, J.M., França, C.R.R.S., Fernandes, S.C., Gomes, T.C.A., Silva, M.S.L., Matos, A.N.B. 2007a. Preparo e uso de biofertilizantes líquidos. Embrapa Semi-Árido, Petrolina, Brasil. 4 p. (Comunicado Técnico, 130).

Silva, A.P., Silveira, J.P.A., Santos, D., Fraga, V.S., Silva, E., Souza, J.M., Lima, L.P.F., Nascimento, J.A.M. 2007b. Respiração edáfica após aplicação de biofertilizantes em cultivo orgânico de milho. Revista Brasileira de Agroecologia 2: 1251-1254.

Silva, F.L., Viana, T.V.A., Sousa, G.G., Costa, S.C., Azevedo, B.M. 2016a. Yield of common fig fertigated with bovine biofertilizer in the semiarid region of Ceará. Revista Caatinga 29: 425-434.

Silva, F.L., Viana, T.V.A., Sousa, G.G., Oliveira, F.M.M., Azevedo, B.M., Silva, G.L. 2018. Ambiência e biofertirrigação na cultura do figo. Revista Brasileira de Agricultura Irrigada 12: 2702-2715.

Silva, J.A., Oliveira, A.P., Alves, G.S., Cavalcante, L.F., Oliveira, A.N.P., Araújo, M.A.M. 2012. Rendimento do inhame adubado com esterco bovino e biofertilizante no 
solo e na folha. Revista Brasileira de Engenharia Agrícola e Ambiental 16: 253-257.

Silva, R.P., Favreto, R., Santin, A., Bertoldo, J.G., Tonietto, A., Abichequer, A.D. 2016b. Calcário e biofertilizante na qualidade e rendimento de frutos de abacaxi 'Pérola'. Pesquisa Agropecuária Gaúcha 22: 25-38.

Soares, C.M.T., Feiden, A., Tavares, S.G. 2017. Fatores que influenciam o processo de digestão anaeróbia na produção de biogás. Nativa 5: 509-514.

Sousa, G.G., Viana, T.V.A, Silva, G.L., Dias, C.N., Azevedo, M.B. 2016. Interação entre salinidade e biofertilizante de caranguejo na cultura do milho. Magistra 28: 44-53.

Sousa, M.F., Silva, L.V., Brito, M.D., Furtado, D.C.M. 2012. Tipos de controle alternativo de pragas e doenças nos cultivos orgânicos no estado de Alagoas, Brasil. Revista Brasileira de Agroecologia 7: 132-138.

Souza, J.T.A, Cavalcante, L.F., Nunes, J.C., Bezerra, F.T.C., Nunes, J.A.S., Silva, A.R., Oresca, D., Cavalcante, A.G. 2016. Effect of saline water, bovine biofertilizer and potassium on yellow passion fruit growth after planting and on soil salinity. African Journal of Agricultural Research 11: 2994-3003.

Taiz, L., Zeiger, E., Møller, I., Murphy, A. 2017. Fisiologia e desenvolvimento vegetal. Artmed, Porto Alegre, Brasil. $888 \mathrm{p}$.

Tal, A. 2018. Making conventional agriculture environmentally friendly: moving beyond the glorification of organic agriculture and the demonization of conventional agriculture. Sustainability 10: 1078-1095.

Trés, F., Resende, S.A. 1995. Supermagro SM: biofertilizante enriquecido. Emater-Rio, Niterói, Brasil. 11 p.

Tullio, L., Morais, H., Yagi, R. 2018. Nutrition, yield and quality of 'Niagara Rosada' vine fruits using cattle slurry and plastic cover. Revista Brasileira de Fruticultura 40: e-59.

Vavilin, V.A., Rytov, S.V., Lokshina, L.Y. 1996. A description of hydrolysis kinetics in anaerobic degradation of particulate organic matter. Bioresource 56: 229-237.

Veras, M.L.M., Melo Filho, J.S., Alves, L.S., Souza, L.M.C., Dias, T.J. 2018. Morphophysiological responses of cowpea to irrigation with saline water and application of bovine biofertilizer. Comunicata Scientiae 9: 509-518.

Veroneze, M.L., Schwantes, D., Gonçalves Jr., A.C., Richart, A., Manfrin, J., Schiller, A.P., Schuba, T.B. 2019. Production of biogas and biofertilizer using anaerobic reactors with swine manure and glycerin doses. Journal of Cleaner Production 213: 176-184.

Viana, T.V.A., Santos, A.P.G., Sousa, G.G., Pinheiro Neto, L.G., Azevedo, B.M., Aquino, B.F. 2013. Trocas gasosas e teores foliares de NPK em meloeiro adubado com biofertilizantes. Revista Brasileira de Ciências Agrárias 8: 595-601.

Wang, M., Chen, S., Han, Y., Chen, L., Wang, D. 2019.
Responses of soil aggregates and bacterial communities to soil-Pb immobilization induced by biofertilizer. Chemosphere 220: 828-836.

Werh, P.P. 2014. Biofertilizantes, a base de esterco bovino, no controle de Phytophthora nicotianae em citrus. $63 \mathrm{f}$. (Dissertação de Mestrado) - Universidade Federal de São Carlos, Araras, Brasil.

Zambolim, L.; Ventura, J. A.; Zanão Júnior, L. A. 2012. Efeito na nutrição de plantas no controle de doença de plantas. Editora UFV, Viçosa, Brasil. 321 p.

Conflict of Interest Statement: The authors declare that the research was conducted in the absence of any commercial or financial relationships that could be construed as a potential conflict of interest.

All the contents of this journal, except where otherwise noted, is licensed under a Creative Commons Attribution License attribuition-type BY. 